\title{
EFFECTS OF ENVIRONMENTAL POLLUTION ON FISH: A SHORT REVIEW
}

Zahra KHOSHNOOD *

* Department of Biology, College of Science, Dezful Branch, Islamic Azad University, Dezful, Azadegan, University Boulevard, Iran, P.O. .Box. 313, ZKhoshnood@gmail.com

DOI: 10.1515/trser-2017-0005

KEYWORDS: heavy metals, herbicide, gill, kidney, liver, histopathology.

\section{ABSTRACT}

Environmental contaminants, such as heavy metals and pesticides, are the most important toxic compounds of aquatic habitats. Heavy metals enter the aquatic environments via natural and anthropogenic pathways while the only source of pesticides is the anthropogenic usage of different types of pesticides including fungicide, insecticide and herbicide. Fish larvae and fingerlings are the most vulnerable life stages of fish which could be severely affected by pesticides as non-target organisms as well as by heavy metal pollution. The most important tissues affected by these pollutants are the gill, kidney and liver. Histopathological alterations of these vital organs could affect the survival rate, biological activities, osmoregulation, reproduction, buoyancy, etc., which finally could lead to failures in stock recruitment and population changes.

ZUSAMMENFASSUNG: Auswirkungen der organischen Gewässerbelastung auf Fische: ein kurzer Überblick.

Umweltgifte wie beispielsweise Schwermetalle und Pestizide sind die wichtigsten toxischen Komponenten aquatischer Lebensräume. Schwermetalle gelangen in die Gewässer über natürliche und anthropogen bedingte Pfade, während die einzige Quelle für Pestizide in der anthropogenen Nutzung ihrer verschiedenen Typen liegt, einschließlich Fungizide, Insektiizide und Herbizide. Fischlarven und Kleinfische sind die verletzlichsten Lebensstadien der Fische, die als Nicht-Zielorganismen stark durch Pestizide, aber auch durch Schwermetallbelastung beeinträchtigt werden. Die durch diese Verschmutzer am stärksten gefährdeten Gewebe sind Kiemen, Nieren und Leber. Histopathologische Veränderungen dieser vitalen Organe können die Überlebensrate, die biologischen Aktivitäten, die osmotischen Vorgänge, Vermehrung, Schwimmfähigkeit etc. gefährden, die schließlich zum Stillstand in der Bestandserweiterung der Fschbestände und zu Populationsveränderungen führen können.

REZUMAT: Efectele poluării mediului asupra peștilor: o scurtă trecere în revistă.

Poluanții precum metalele grele și pesticidele sunt cele mai importante componente toxice din habitatele acvatice. Metalele grele pătrund în mediile acvatice pe căi naturale și antropice în timp ce pesticidele au o singură sursă, anume utilizarea de către om a diferitor tipuri de pesticide, inclusiv fungicide, insecticide și ierbicide. Larvele și alevinii sunt stadiile cele mai vulnerabile în cazul peștilor, care pot fi afectați grav de poluarea cu pesticide deși nu sunt organismele vizate de acestea, dar și de cea cu metale grele. Principalele țesuturi afectate de acești poluanți sunt branhiile, rinichii și ficatul. Modificările histopatologice ale acestor organe vitale pot afecta rata de supraviețuire, activitatea biologică, osmoreglarea, reproducerea ș.a.m.d., ceea ce se poate traduce în final în incapacitatea refacerii stocurilor și în modificări de ordin populațional. 


\section{INTRODUCTION}

Pollution and the effects of various pollutants on fish has been researched and is still under study. The most numerous contaminants are heavy metals and pesticides; even if there are up-to-date researches on the impact of nano-particles (Khoshnood, 2016).

Heavy metals are one of the most studied contaminants worldwide. It has been shown that they reach in to the aquatic ecosystems in a number of different ways. Two major pathways have been shown: natural and anthropogenic. As natural ways for heavy metals entering aquatic environments one can name: volcanic activity (terrestrial or marine), windblown dust, forest fires and erosion of ore bearing rocks (Khoshnood et al., 2012).

Anthropogenic pathway of heavy metals is due to urban, agricultural and industrial wastewater and dumping of solid waste in coastal environments. Despite the large scale of natural source for heavy metals, it has been estimated that the anthropogenic source for such heavy metals $(\mathrm{Hg}, \mathrm{Pb}, \mathrm{Zn}, \mathrm{Cd}$ and $\mathrm{Cu})$ are about one to three orders of magnitude greater than natural release. The principal cause of anthropogenic pollution of heavy metals is industrial wastewater which influenced the various aquatic environments such as ponds, lakes, streams, rivers, seas and oceans (Khoshnood et al., 2012).

Worldwide usage of pesticides and high diverseness of all these substances make them as one of the most important contaminants of aquatic habitats. Beside their impact on target organisms, the impact of these contaminants on non-target organisms is high (Khoshnood, 2016). It has been estimated that a large part of used insecticides and herbicides (about over 98\% and 95\%) reach to the non-target organisms (USEPA, 2002). Different ways of motility for these compounds has been described, for instance, wind can carry out the pesticides from one field to another, runoff (from excessive watering system or rain) can lead them to different water bodies, even undergrounds water reservoirs; and by all these ways pesticides can affect the non-target organisms. Human flaws during different stages of pesticide production, transportation, storage and usage are also affects the other species (USEPA, 2002).

However, wide variety of pesticides has different environmental destination and activity due to their specific chemical properties. Due to undesirable effects of pesticides on non-target organisms, many of these compounds have been banned through time and also many others are under strict regulations for use. Also for reducing their effects on non-target organisms, today pesticides are more species-specific, less motile and less persistent (Khoshnood et al., 2014).

\section{Effects on different life stages}

All organisms have a life cycle with different stages in which some stages are more vulnerable to environmental alterations and contaminants than the others. It has been shown than the most sensitive stages of fish life cycle is the early developmental stages such as embryonic and larval stages. Beside the long time exposure to low levels of contaminants which could seriously impact the organism, it has been underlined that also short time exposure could influence the feeding and buoyancy behaviors, osmotic regulation, growth and survival of the organism and because of that negatively influence the recruitment of population (Khoshnood, 2016). 


\section{Fish tissues as biomarker}

The biomarker concept is using for biological alteration associated to environmental pollutants and risks which could be physical, chemical and/or biological (Van der Oost et al., 2003).

In the past two decades, usage of biomarkers as an effective tool in environmental contamination studies of aquatic habitats has been developed.

In the present, a large range of researches, such as biochemical, molecular, physiological, morphological, histopathological, community, and population, are use in monitor the impact of various pollutants, various concentrations of a single contaminant, environmental quality, or the habitat and ecosystem succession (Khoshnood, 2016).

Histology is a useful tool to assess the exposure to contaminants such as the degree of pollution in acute, sublethal and chronic exposure (Bernet et al., 1999).

Generally, using molecular and biochemical biomarkers are more accurate and specific but linking them to environmental alterations is more difficult. Changes in population responses are conveniently to link with environmental health and management, even if researching of such feedback was more labored, less specific and only become detectable once the ecosystem has damaged.

Researching of histocytopathological modifications is average easy and is largely used as biomarkers in various observations on the effects of pollutants on environmental health including on fish (Khoshnood, 2016).

Several tissues and organs of various fish were repeatedly used as biomarker of fish contamination due to their specific characteristics. Among these organs, the gill is one of the most common tissues in environmental contamination studies due to its wide surface area in contact with surrounding water, high activity in ion transport, high amount of blood, etc. (Khoshnood, 2016).

Other common tissues in such studies include the liver, kidney, intestine, skin and brain. All these tissues have important roles in life of a fish and some, such as liver, has metabolic pathways for eliminating the contaminants (Khoshnood, 2016).

\section{Effects of heavy metals on fish \\ Gill}

Gills are one of the most important organs of all fish because of the wide surface area with surrounding water. As a result, the respiratory system is frequently the first organ to be affected by pollutants (Khoshnood et al., 2011).

One of the most frequent heavy metals in aquatic environments is mercury, which received a great deal of attention after discovery of Minamata disease in Japan in the 1950s. It is revealed that the fate of mercury compounds in the environment greatly depends on the chemical form of mercury and the environmental conditions (Beckvar et al., 1996).

$\mathrm{HgCl}_{2}$ is one of the inorganic forms of mercury in polluted aquatic environments. Results of a case study on the effects of $\mathrm{HgCl}_{2}$ on Persian sturgeon, Acipenser persicus, fry, showed that at the short term exposure (acute) of fish to a low level of $\mathrm{HgCl}_{2}$ as $15 \mathrm{ppb}$ for 48 hours a wide variety of changes in gill tissue can be happen (Khoshnood et al., 2011). Hypertrophy of epithelial cells in lamellae, wrinkling of lamellar epithelium, fusion of lamellae, and lamellar hyperplasia (Figs. 1A-E) were the most important alterations observed in that study (Khoshnood et al., 2011). Ultrastructural observation of gills affected by $\mathrm{HgCl}_{2}$ showed some major alterations such as necrosis in filaments and bleeding (Fig. 1F) (Khoshnood et al., 2011). 

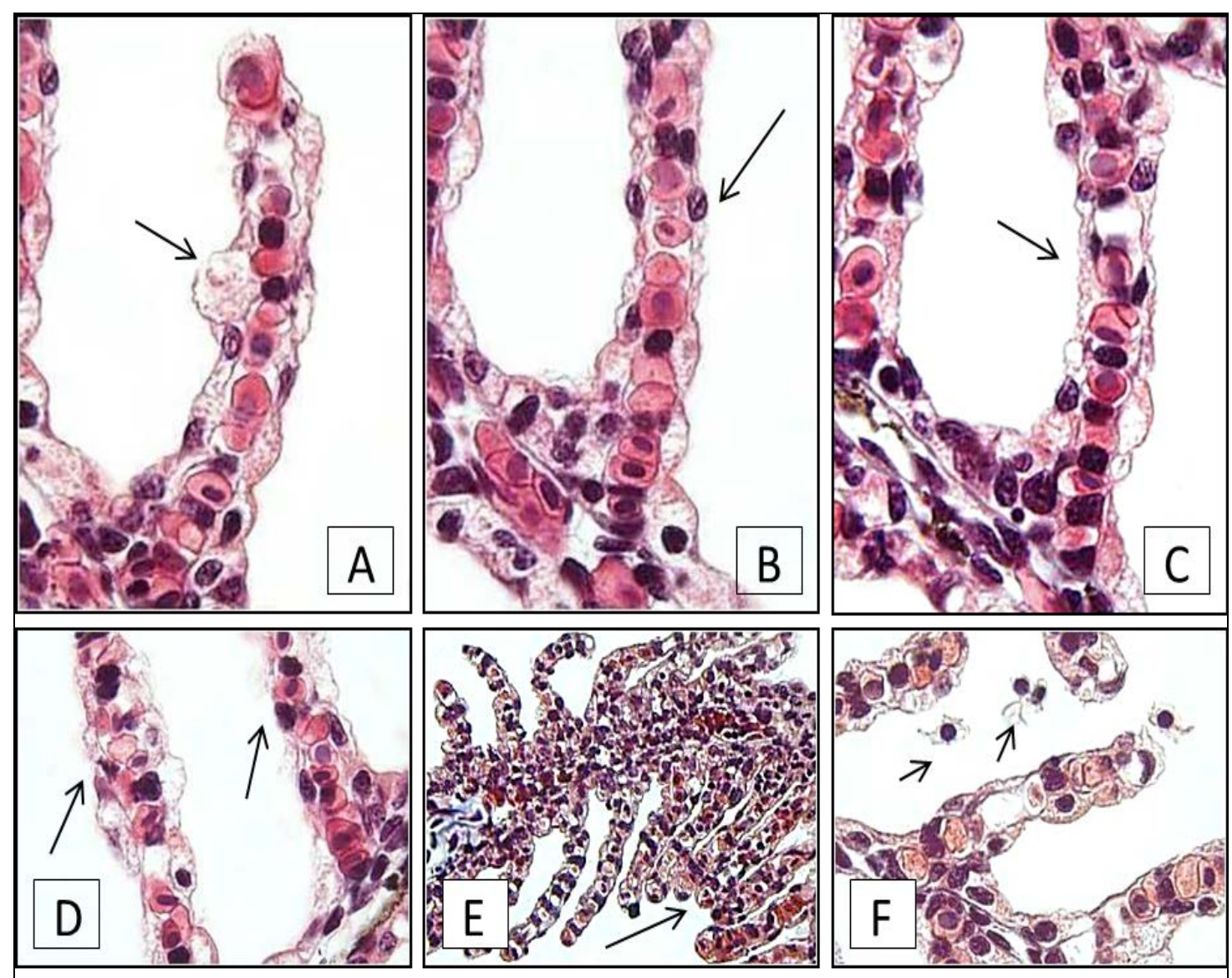

Figure 1: Histopathological effects of $\mathrm{HgCl}_{2}$ on gills of Persian sturgeon, Acipenser persicus fry: Hypertrophy of the epithelial cell in lamellae (A). Wrinkling of the epithelium (B and C). Epithelial hyperplasia and epithelial necrosis without blood outcoming (D). Lamellae fusion

(E). Necrosis in epithelium with blood outcoming (F) (Khoshnood et al., 2011)

\section{Liver}

In a previous study on the bioaccumulation of heavy metals, $\mathrm{Ni}$ and $\mathrm{V}$ in two flat fishes, Euryglossa orientalis and Psettodes erume, had revealed that pollution of water with these two metals could affect the liver tissue and make some histopathological alterations. These alterations include degeneration and necrosis of hepatocytes, tissue disruption and haemorrhagie (Figs. 2A-D) (Khoshnood et al., 2010). 


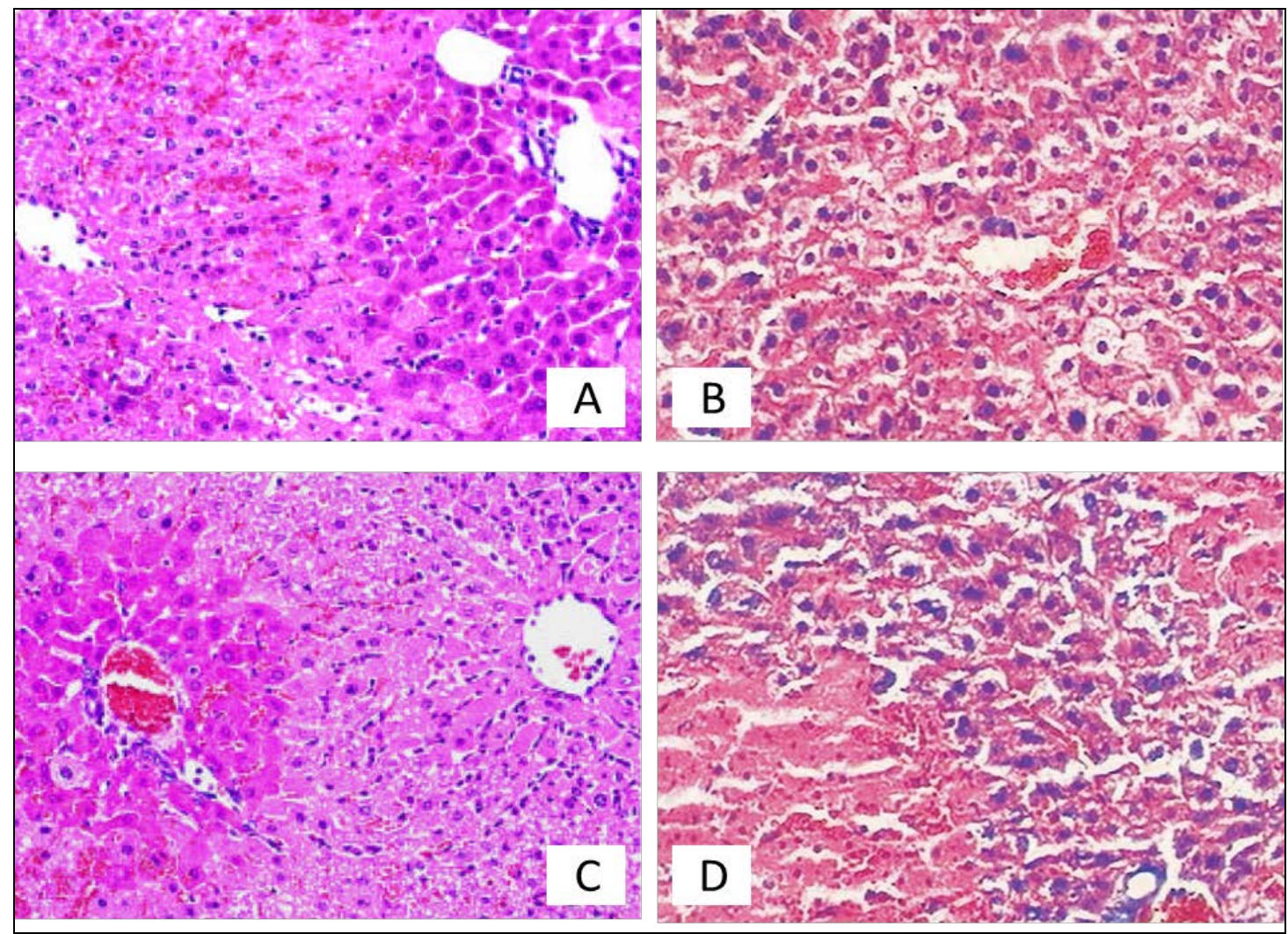

Figure 2: Histopathological alterations in liver of two flat fishes, P. erumei (A and B) and

E. orientalis (C and D): Hemorrhagia, cell necrosis and degeneration were the most histopathological alterations (Khoshnood et al., 2010).

\section{Effects of pesticides on fish}

Pesticides include a wide range of compounds including insecticides, fungicides, herbicides, etc., each divided to subgroups of their chemical forms. Among the pesticides, due to the agricultural activities, herbicides represent a large percent of all used pesticides worldwide. One of the most common herbicide is atrazine, which affects the photosynthesis in broad leaf plants and has well known effects on different non-target organisms including frogs, birds, fish and even humans (Giddings et al., 2004).

\section{Gill}

In revealing of the impact of atrazine on Caspian kutum, Rutilus frisii kutum, fry, it has been underlined that important tissue and cell modifications could be seen due to acute exposure to a sublethal concentration of atrazine as low as $12.47 \mathrm{mgl}^{-1}$.

These alterations include detachment of the epithelium of the lamellae (Figs. 3A-F, 4E-G), necrosis (Figs. 3C-F, 4J, 5D), lamellar fusion (Figs. 3B, D, E, F, 4C, 5A-D), hyperplasia (Fig. 4C), club shaped lamellae (Figs. 4A and $\mathrm{H}$ ), collapse of the lamellae (Figs. 5A-D), shrinkage and curling of the lamellae (Figs. 4H, 5A-C), and ultrastructural alterations such as necrosis of the apical microridges of the pavement cells (Fig. 5D). Results of this also showed that the gill ionocytes were fewer in number and larger in size in the atrazine-exposed fish (Khoshnood et al., 2015). 

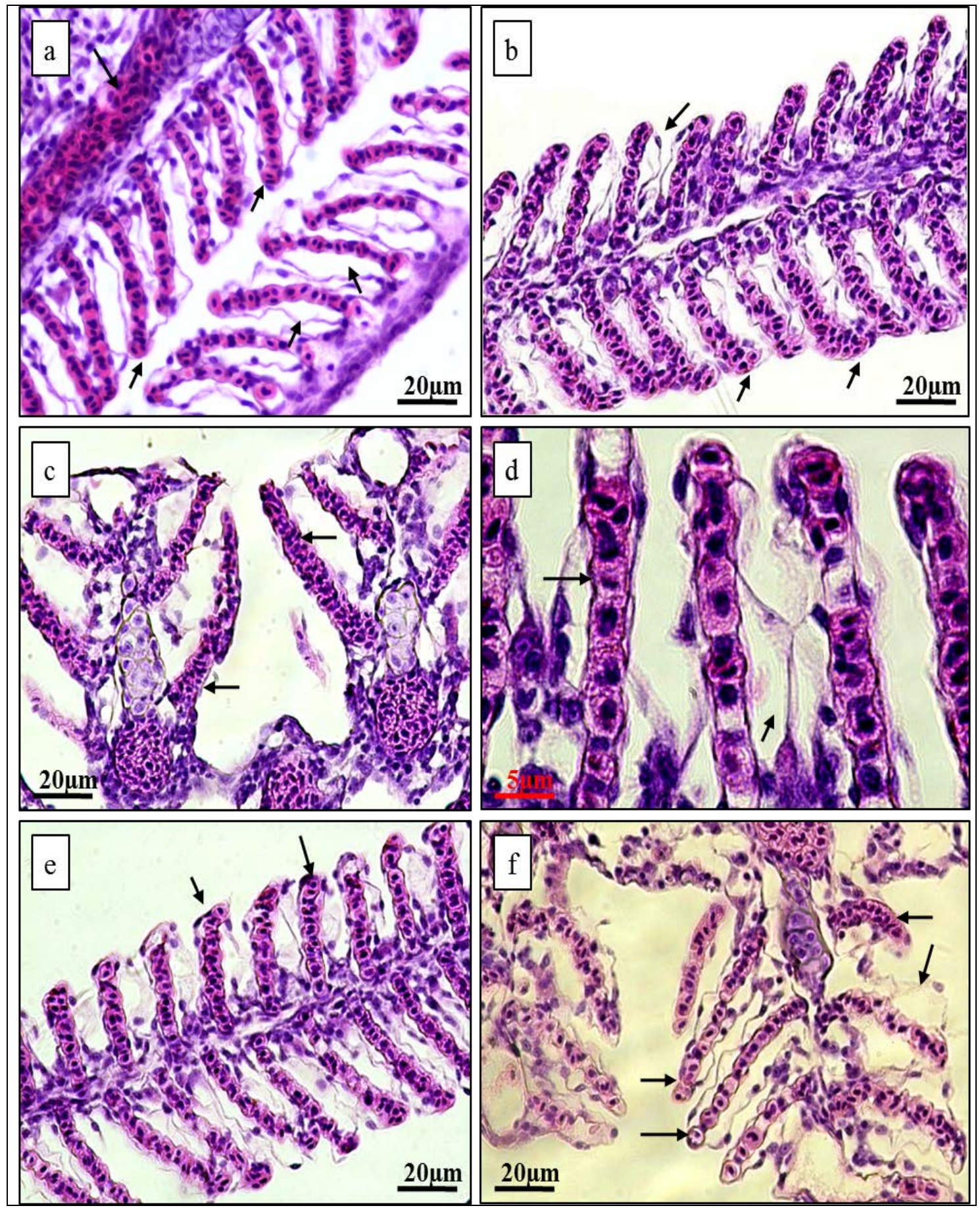

Figure 3: Histopathological effects of atrazine on gills of Rutilus frisii kutum, Fingerlings: Lifting up the lamellar epithelium (a and f); thickening of the lamellae (b);

blood congestion (a-f); edema in lamellae and filament (b and e); hypertrophy of the pavement cells of the lamellae (d); necrosis (c and f); lamellar fusion (b, d, e and f)

(Khoshnood et al., 2015). 




Figure 4: Additional histopathological effects of atrazine on gills of Rutilus frisii kutum, Fingerlings: Hyperplasia of the filament's epithelium (a); club shaped lamellae (a and h); lifting up the epithelium of the gill racker (b); hyperplasia of the lamellar epithelium and lamellar fusion (c); edema in epithelium of the filament and the cells at the basis of the lamellae (d, $\mathrm{f}$ and i); edema in pavement cells of the lamellae and lifting up of this epithelium (e); blood congestion (f-j); shrinkage of the lamellae (h); necrosis in lamellar epithelium (j) were the most recognizable changes made by atrazine exposure (Khoshnood et al., 2015). 


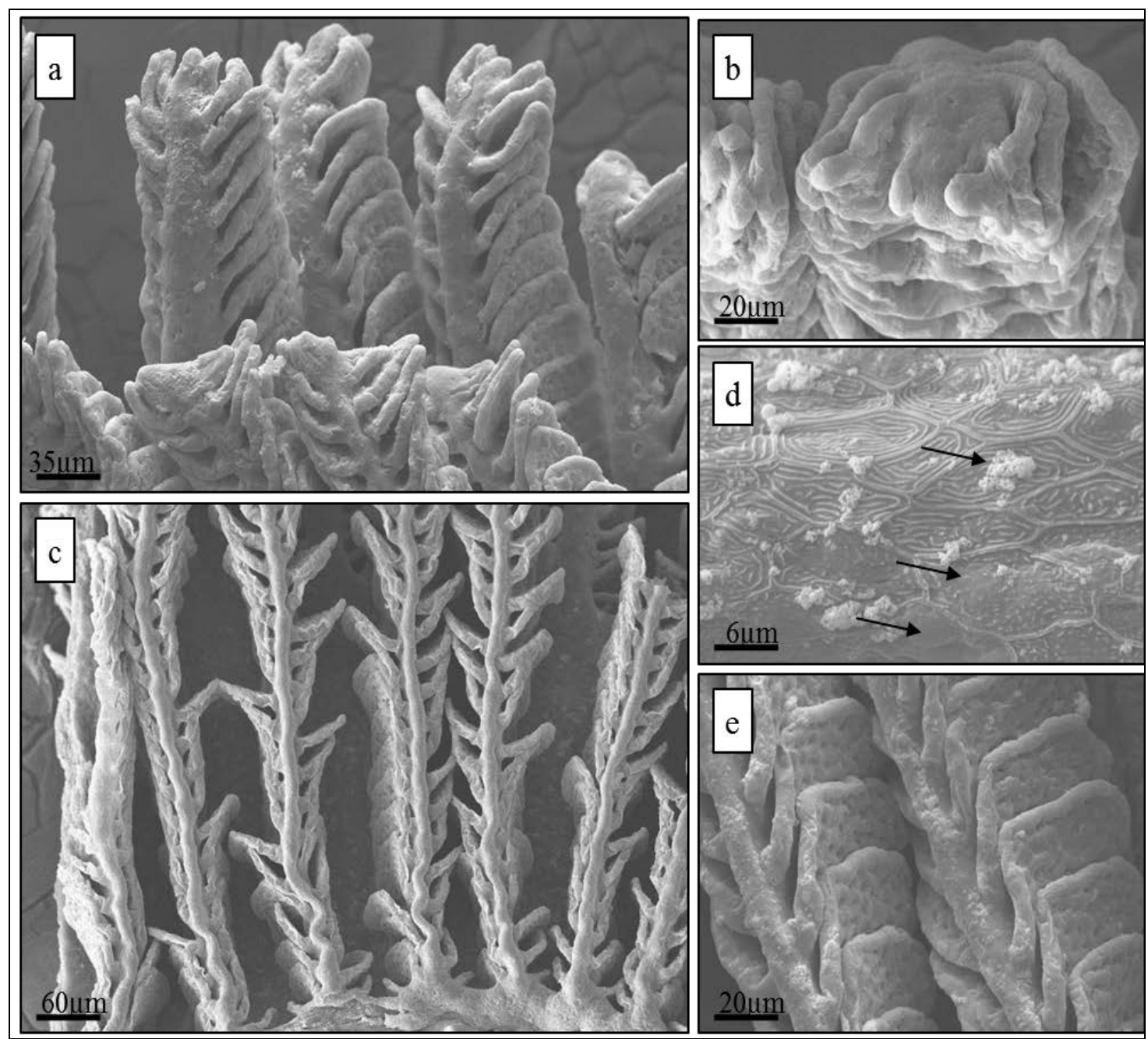

Figure 5: ultrastructural effects of atrazine on gills of Rutilus frisii kutum, fingerlings;

fusion and collapsing of the lamellae (a, b, c and d); shrinkage and curling of the lamellae at the apical parts of the filaments (a-c); necrosis of the apical microridges of the pavement cells and mucus aggregation (d) (Khoshnood et al., 2015).

\section{Kidney}

In a study of the effects of atrazine herbicide during two stages of the life cycle of Caspian kutum, Rutilus frisii kutum, for larvae and fry it was found that the damages were more severe in larvae than the fingerlings. The major histopathological effects of acute exposure to a sublethal concentration of atrazine $(9.25 \mathrm{ppm}$ and $12.47 \mathrm{ppm}$ for larvae and fry respectively, both for $96 \mathrm{~h}$ ) were hyperplasia (Figs. 6E, 7B-C), necrosis (Figs. 6C, F, 7A-D), vacuolation (Figs. 6D-F), swelling (Figs. 6D-F, 7F), hypertrophy (Figs. 6D-F), aggregation of hyaline droplets (Figs. 6D-F), and disruption of the haematopitic tissue of the head kidney (Fig. 6C) (Khoshnood, 2015). 


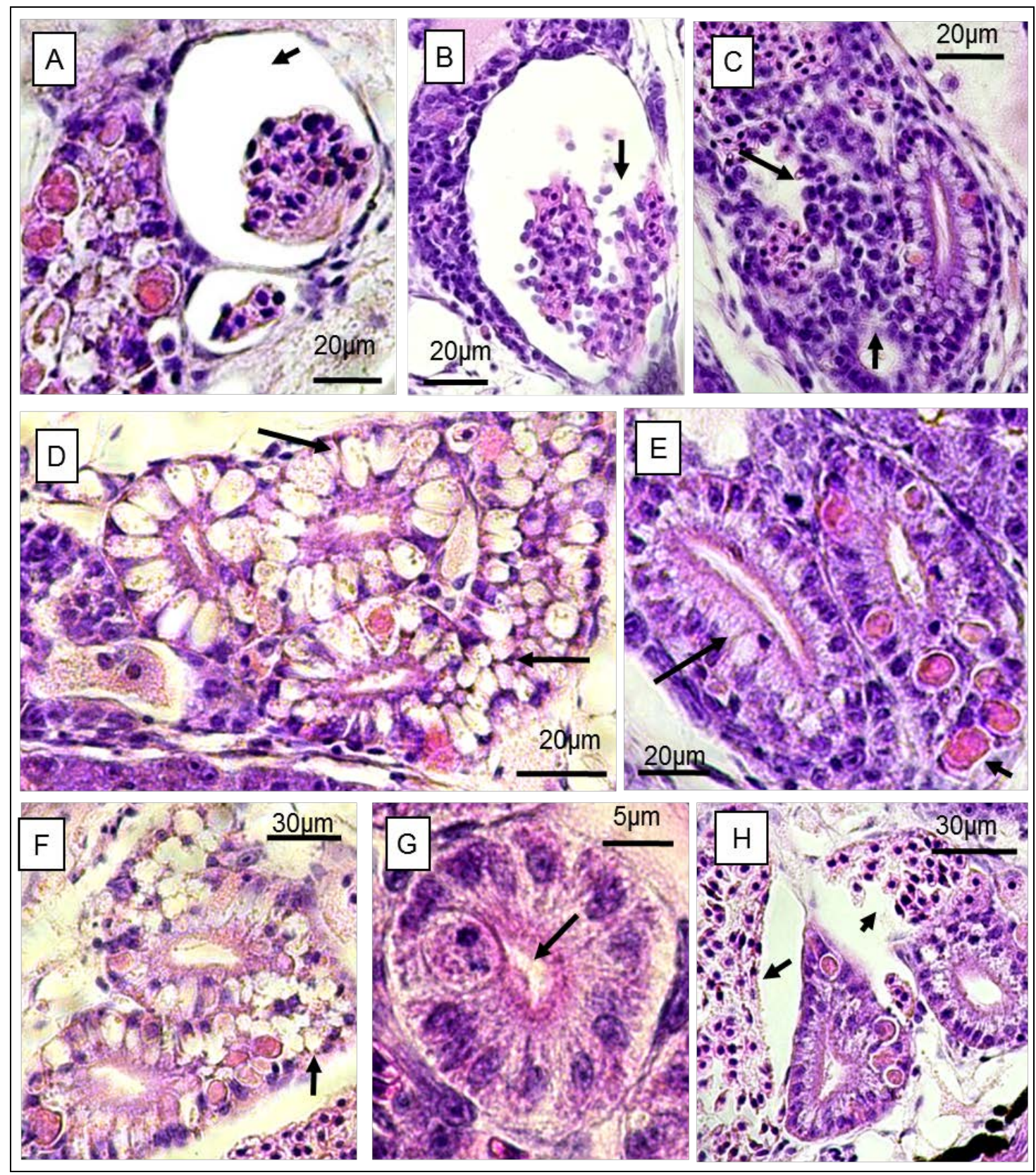

Figure 6: Histopathological effects of atrazine on kidney of $R$. frisii kutum larvae: reduction of the glomerulus and increasing of the Bowman's space (A); necrosis of the glomerulus (B); necrosis and disruption of the haematopitic tissue of the head kidney (C); swelling, hypertrophy, vacuolation and aggregation of hyaline droplets in renal tubular epithelial cells (D-F); hyperplasia of the renal tubular epithelial cells (E); necrosis of the renal tubular epithelial cells (F); decreasing in lumen space and complete congestion of lumen in renal tubules (G); hyperemia (H) (Khoshnood, 2015). 


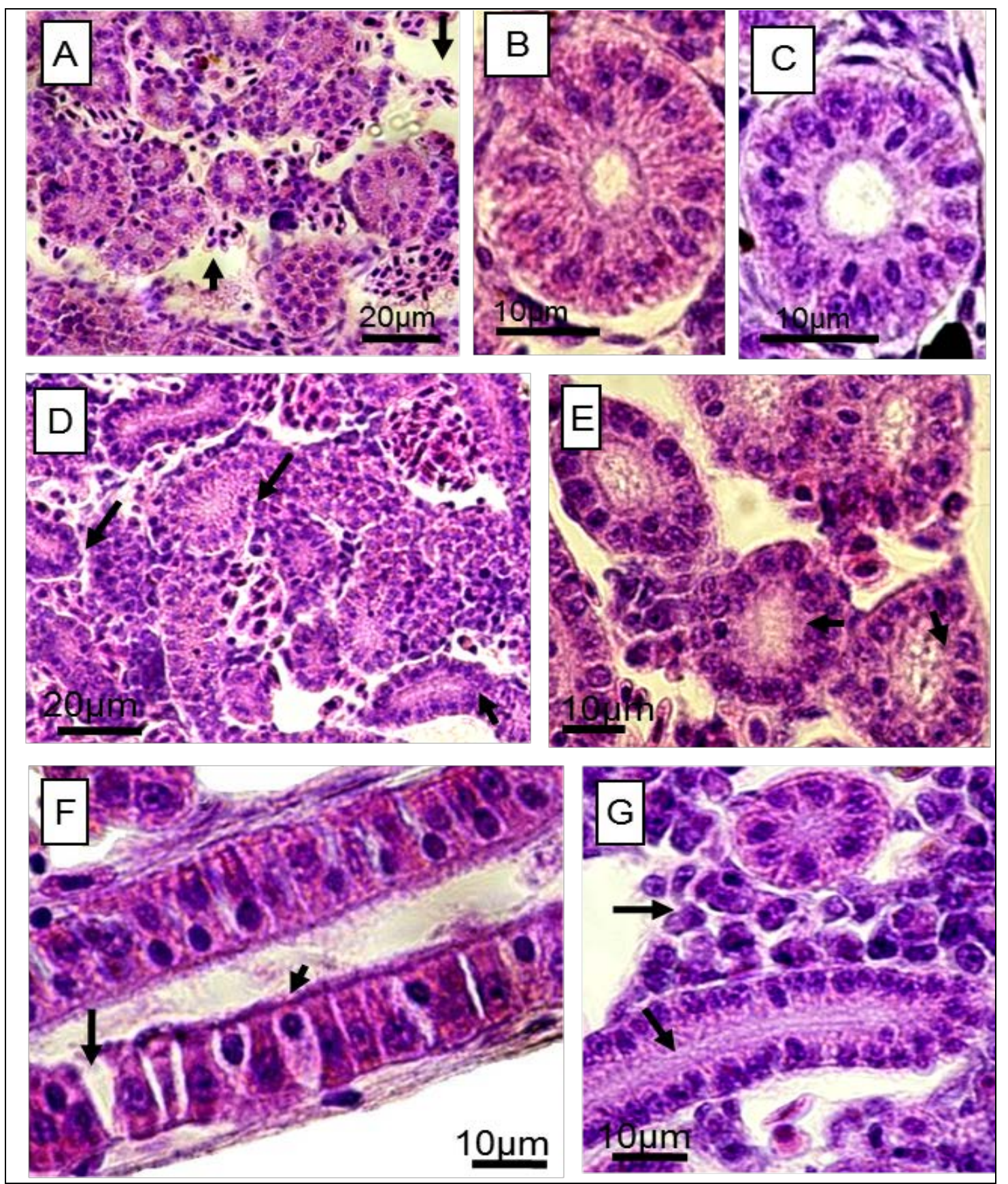

Figure 7: Histopathological effects of atrazine on kidney of $R$. frisii kutum fingerlings: hyperplasia of proximal tubule epithelial cells (B, C) and detachment of epithelial cells from the basement membrane (B, C), Congestion of tubular lumen (D, E, G); necrosis and disruption of haematopoitic tissue in head kidney (A, D); necrosis, swelling and disorientation of ureter epithelial cells (F) (Khoshnood, 2015). 


\section{CONCLUSIONS}

Results showed that environmental contaminants such as heavy metals and herbicides could affect multiple tissues of fish (gill, liver and kidney), even at low concentrations and acute exposure. Tissue modifications of all these essential organs will decrease the survival rate and biological activities level of organisms such as osmotic regulation, feeding, buoyancy, etc., which lead to population diminution.

Results showed that due to high surface to volume ratio of smaller organism (larvae compare to fingerlings) and also the high rate of cell growth and differentiation in larvae, the effects of environmental contamination on larvae will be more severe than the effects on fingerlings. The results also showed that many tissue alterations made by these environmental contaminants were not specific but generally could be used as a monitoring tool in environmental protection programs. 


\section{REFERENCES}

1. Beckvar N., Field J., Salazar S. and Hoff R., 1996 - Contaminants in Aquatic Habitats at Hazardous Waste Sites: Mercury, NOAA Technical Memorandum NOS ORCA 100, Hazardous Materials Response and Assessment Division, National Oceanic and Atmospheric Administration, 74.

2. $\quad$ Bernet D., Schmidt H., Meier W., Burkhardt-Holm P. and Wahli T., 1999 - Histopathology in fish: proposal for a protocol to assess aquatic pollution, Journal of Fish Diseases, 22, 25-34.

3. Giddings J. M., Anderson T. A., Hall Jr. L. W., Kendall R. J., Richards R. P., Solomon K. R. and Williams W. M., 2004 - A probabilistic aquatic ecological risk assessment of atrazine in north American surface waters, SETAC Press, Pensacola, Florida, USA.

4. Khoshnood Z., 2015 - Histopathological Alterations in the Kidney of Caspian Kutum, Rutilus frisii kutum, Larvae and Fingerlings Exposed to Sublethal Concentration of Atrazine, Bulletin of Environmental Contamination and Toxicology, 94, 158-163.

5. Khoshnood Z., 2016 - Using Biomarkers in Ecotoxicology: What and Why? Focus on Sciences, 2, 2, 1-2.

6. Khoshnood Z., Khodabandeh S., Shahryari Moghaddam M. and Mosafer Khorjestan S., 2011 Histopathological and Pathomorphological Effects of Mercuric Chloride on the Gills of Persian Sturgeon, Acipenser persicus, Fry, International Journal of Natural Resources and Marine Sciences, 1, 1, 23-32.

7. Khoshnood Z., Khoshnood R., Mokhelsi A., Ehsanpour M., Afkhami M. and Khazaali A., 2012 - Determination of $\mathrm{Cd}, \mathrm{Pb}, \mathrm{Hg}, \mathrm{Cu}, \mathrm{Fe}, \mathrm{Mn}, \mathrm{Al}, \mathrm{As}, \mathrm{Ni}$ and $\mathrm{Zn}$ in important commercial fish species in northern of Persian Gulf, Journal of Cell and Animal Biology, 6, 1, 1-9.

8. Khoshnood Z., Jamili S. and Khodabandeh S., 2015 - Histopathological effects of atrazine on gills of Caspian kutum Rutilus frisii kutum fingerlings, Diseases of aquatic organisms, 113, 227234.

9. Khoshnood Z., Jamili S., Khodabandeh S., Mashinchian Moradi A. and Motallebi Moghanjoghi A. A., 2014 - Histopathological effects and toxicity of atrazine herbicide in Caspian Kutum, Rutilus frisii kutum, fry, Iranian Journal of Fisheries Sciences, 13, 3, 702-718.

10. USEPA (U.S. Environmental Protection Agency), 2002 - Registration eligibility science chapter for atrazine environmental fate and effects chapter. Washington, DC, USA. Available online at http://www.epa.gov/oppsrrd1/reregistration/atrazine/efed_redchap_22apr02.pdf.

11. Van der Oost R., Beyer J. and Vermeulen N. P., 2003 - Fish bioaccumulation and biomarkers in environmental risk assessment: a review, Environmental Toxicology and Pharmacology, 13, 2, 57-149. 